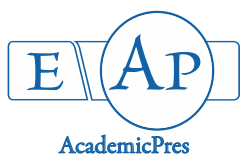

Amari A et al. (2021)

Notulae Scientia Biologicae

Volume 13, Issue 2, Article number 10961

DOI: $10.15835 /$ nsb13210961

Research Article

\title{
Ethnopharmacological survey of medicinal plants used to treat cutaneous leishmaniasis in Ain Sekhouna, Saida, Algeria
}

\author{
Asmaa AMARI ${ }^{1 *}$, Kadda HACHEM ${ }^{2,3}$, Maya M. HASSANI ${ }^{3}$ \\ ${ }^{1}$ Djillali Liabes University Sidi-Bel-Abbès, Faculty of Nature and Life Sciences, Department of Environmental Sciences, Laboratory \\ for the Eco-development of Spaces, BP 89,22000 Sidi-Bel-Abbès, Algeria; asmaa.amari@univ-sba.dz (*corresponding author) \\ ${ }^{2}$ University of Saida - Dr. Tahar Moulay, Faculty of Sciences, Department of Biology, Laboratory of Biotoxicology, Pharmacognosy \\ and Biological Valorization of Plants (LBPBVP),BP 138 ENNASR, 20000 Saida, Algeria; hachem.kadda@univ-saida.dz \\ ${ }^{3}$ University of Saida - Dr. Tahar Moulay, Faculty of Sciences, Department of Biology, BP 138 ENNASR, 20000 Saida, \\ Algeria;mayahassani@live.com
}

\begin{abstract}
Cutaneous leishmaniasis is a common anthropozoonosis and a major public health problem in Algeria. Therefore, we conducted an ethnopharmacological survey in the locality of Ain Sekhouna (located in the highlands of western Algeria), one of the foci of cutaneous leishmaniasis. We aimed to identify the medicinal plants and natural remedies used by the local population to treatment cutaneous leishmaniasis. We identified three plant species, belonging to three distinct families, used as natural remedies against the disease, namely, Haloxylon scoparium Pomel (Chenopodiaceae, 73\%), Artemisia herba-alba Asso. (Asteraceae, 18\%), and Camellia sinensis L. (Theaceae, 9\%). Additionally, 35\% of the plant-based medicines mostly comprised the powdered form of the aerial parts of the plant. According to the respondents, the powder is combined with butter, cade oil, or honey and is applied exogenously on the skin. Overall, these medicinal plants can be used as a source of natural medicines, in combination with commonly used dermatological excipients, to treat cutaneous leishmaniasis.
\end{abstract}

Keywords: Ain Sekhouna; Algeria; cutaneous leishmaniasis; ethnopharmacological survey; medicinal plant; natural remedy

\section{Introduction}

Cutaneous leishmaniasis (CL), a global public health problem, is endemic to more than 70 countries, with an estimated annual incidence of 1,500,000 individuals (Bhutto, 2003; Jones, 2005). Cutaneous leishmaniasis is caused by the infection of a flagellated protozoan (Kinetoplastea of the genus Leishmania), which is transmitted by the bite of a small hematophagous midge of the subfamily Phlebotominae.

Cutaneous leishmaniasis is a serious public health concern in Algeria. The recrudescence and spread of the disease to regions close to the foci of infection necessitates an increased surveillance of the evolution of this zoonosis and the application of adequate control measures (Harrat et al., 1995).

The first-line treatment of CL involves the administration of pentavalent antimony salts, $8.5 \% \mathrm{~N}$ methyl-D-glucamine and $10 \%$ sodium stibogluconate, by a health provider, and they are available in the form

Received: 30 Apr 2021. Received in revised form: 26 May 2021. Accepted: 02 Jun 2021. Published online: 07 Jun 2021. From Volume 13, Issue 1, 2021, Notulae Scientia Biologicae journal uses article numbers in place of the traditional method of continuous pagination through the volume. The journal will continue to appear quarterly, as before, with four annual numbers. 
of injectable ampoules. It is recommended to evaluate the cardiac, renal, and hepatic statuses of patients before and during treatment, because high doses of pentavalent antimony salts can cause health problems such as cardiotoxicity and nephrotoxicity (McGwire and Satoskar, 2013). In addition, some strains of Leishmania responsible for CL and mucocutaneous leishmaniasis exhibit resistance to these drugs (Grogl, 1992).

Phytotherapy, that is, the treatment of diseases and infections with plants, has been used for centuries, and medicinal plants have been as a source of medical care in developing countries (Tabuti et al., 2003). According to the World Health Organization, more than $80 \%$ of the African population uses traditional medicines and pharmacopeia to address health problems (Sahli et al., 2010), because medicinal plants not only possess healing properties, but also support proper functioning of the human body (Bigo, 2011).

Algeria is a Mediterranean country with an age-old medical tradition and a population with conventional knowledge of medicinal plants. There are several studies on various plants used to treat a wide range of diseases in Algeria (Benarba et al., 2015; Miara et al., 2018; Hamza et al., 2019). However, only a few studies have reported the use of medicinal plants to treat CL. Therefore, in the present study, we aimed to identify medicinal plants that are effective against $\mathrm{CL}$ and could be used as alternatives to the drugs used to treat CL, which have severe adverse effects.

\section{Materials and Methods}

\section{Studyarea}

The study was undertaken in the municipality of Ain Sekhouna (34 30' 26" N, $0^{\circ} 50^{\prime} 46^{\prime \prime}$ E; altitude: $900 \mathrm{~m}$ ) (Figure 1), which is located to the south of Saida in Algeria and is approximately $90 \mathrm{~km}$ long, with an important hydrographic network. It covers an area of $404.40 \mathrm{~km}^{2}$ (15\% of Sebkha). The commune of Ain Sekhouna is surrounded in the north and west by the commune of El Maamoura, on the east and north by the wilaya of Tiaret, and on the south by the wilaya of El Bayadh (Anteur, 2016).

The climate of Ain Sekhouna is semi-arid, with cold winters and hot summers. The average annual temperature is approximately $14.8^{\circ} \mathrm{C}$ and the average annual rainfall is $276 \mathrm{~mm}$, distributed over $47 \mathrm{~d}$. The average relative humidity ranges from $74.5 \%$ in December to $37 \%$ in July, and the area is subjected to strong winds that blow from the northwest in winters and from the south in summers. Siroccos are frequent, and they last for an average of $22 \mathrm{~d}$ per year.
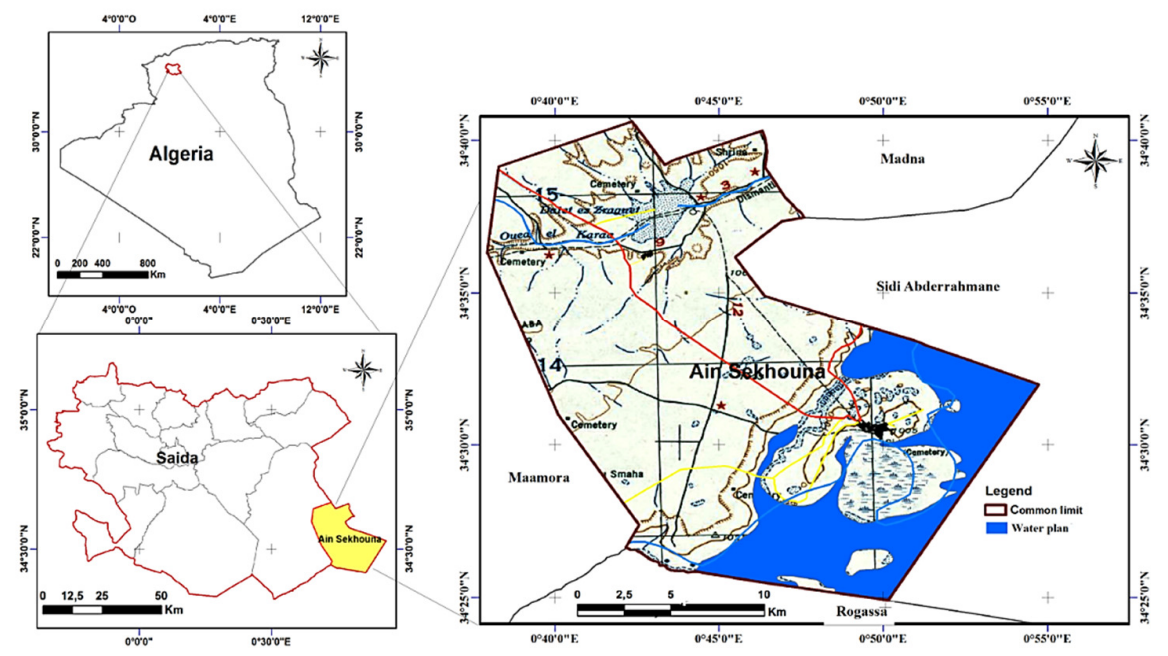

Figure 1. Location of the study area Ain Sekhouna 


\section{Population surveyed}

A total of 100 people (approximately $3 \%$ of the population) out of 3,500 inhabitants, 68 women and 32 men of different ages, were interviewed. The survey parameters and the interviewees' responses were recorded in the form of a questionnaire (Table 1) that was provided to the respondents during the interview.

Table 1. Questionnaire: Medicinal plants with anti-cutaneous leishmanial activity

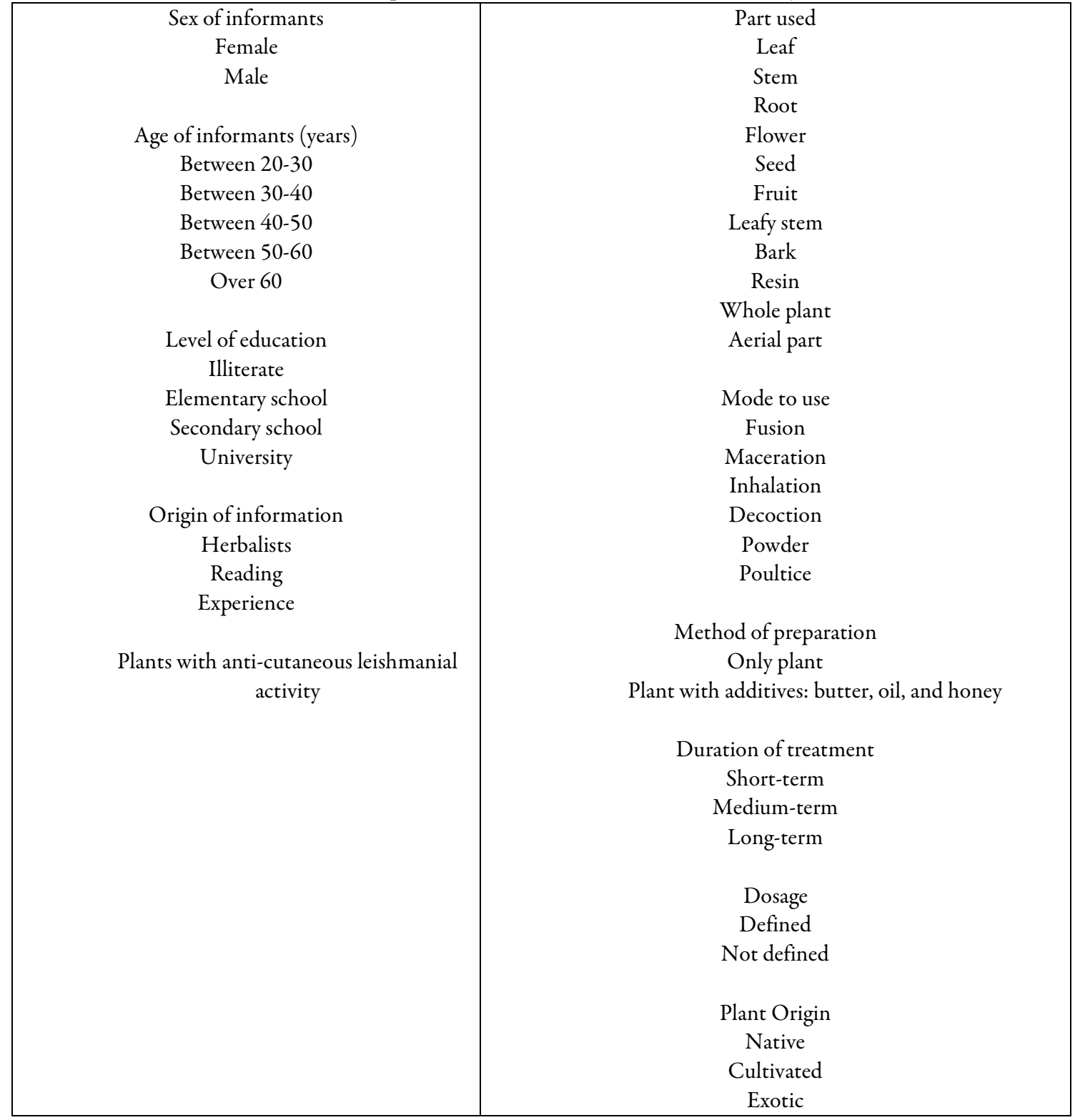

During the interviews, information on the medicinal plants used to treat CL, along with the profile of each respondent, including their sex, age, level of education, and the origin of their information on the plants used, was collected. Moreover, the data collected for each plant included the part used and preparation method of the remedy. Taxonomic identification of each species was carried out by the botanists of the Biology Department, University of Saida, using botanical descriptions from literature.

The information recorded on raw data sheets was transferred to a database, processed, and analyzed (Benabdesslem et al., 2017). 


\section{Results}

Medicinal plant species used to treat $C L$

All respondents of the interviews were literates, with different levels of education (22\% university-, $65 \%$ secondary-, and $13 \%$ primary-levels). Each respondent claimed to have some prior knowledge of CL and conventional medicinal plants used to treat CL. Moreover, $68 \%$ of the respondents claimed that at least one member of their family was previously affected by CL.

Based on the survey, the following three plant species were identified for treating CL (Figure2): Haloxylon scoparium Pomel, reported by $73 \%$ of the respondents, followed by Artemisia herba-alba Asso. (Asteraceae) and Camellia sinensis L. (Theaceae), reported by $18 \%$ and $9 \%$ of the respondents, respectively.

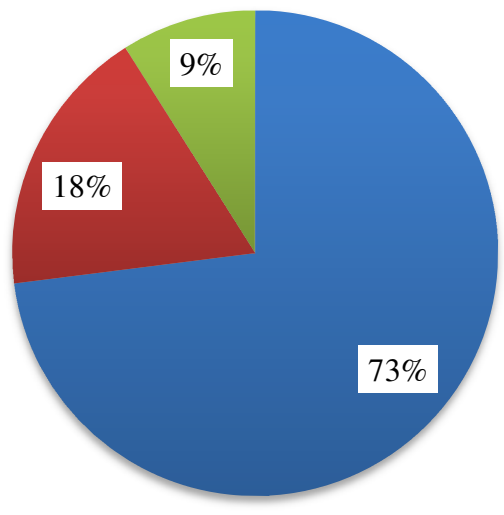

Haloxylon scoparium

- Artimisia herba alba

- Camellia sinensis

Figure 2. Medicinal plants reported as potential remedies for cutaneous leishmaniasis by the respondents of the survey

Haloxylon scoparium was reported as an effective treatment for CL by the respondents of all age groups, with the maximum use by people aged 50-60 years (22\% respondents). Artemisia herba-alba was mostly used by individuals in the age group of 30-40 years (7.5\% respondents), whereas, Camellia sinensis was used by individuals of different age groups (not exceeding $2.5 \%$ of the respondents) (Figure 3 ).

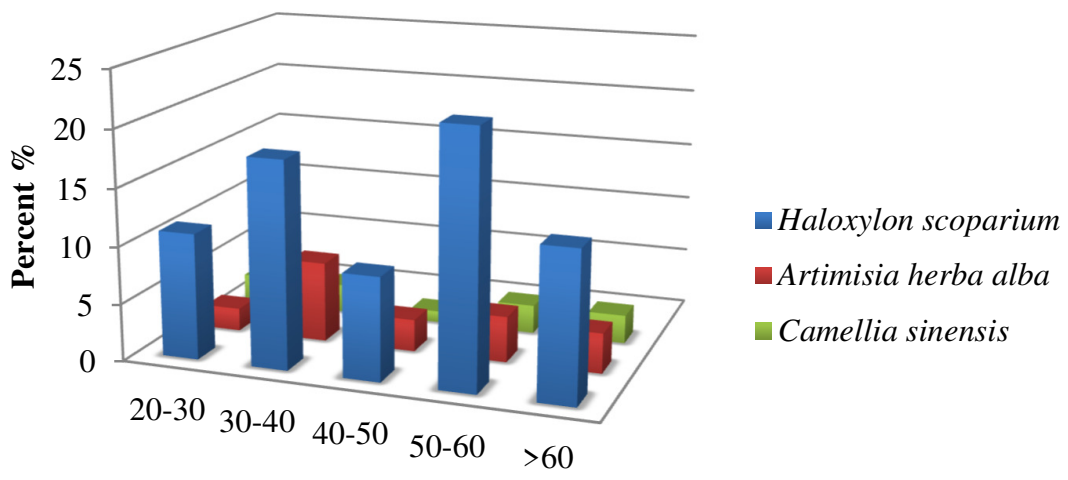

Age of informants

Figure 3. Frequency distribution of medicinal plant species used by the respondents of different age groups 
Parts of the medicinal plant species used to treat $C L$

The survey revealed that the aerial parts of the three plant species were predominantly used to treat CL: H. scoparium, 35\% and A. herba-alba and C. sinensis, approximately 10\% (Figure 4).

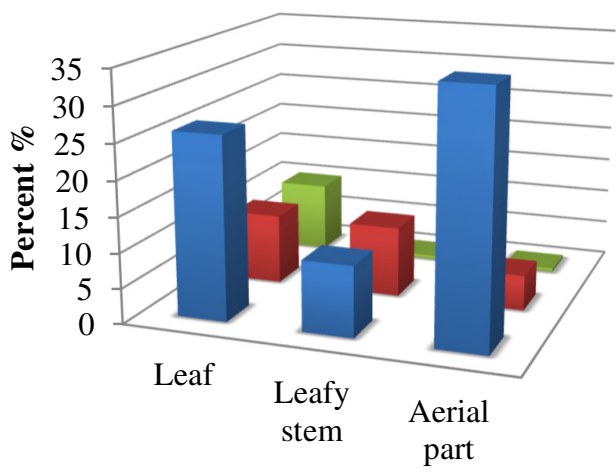

Parts of plant used
- Haloxylon scoparium

- Artimisia herba alba

- Camellia sinensis

Figure 4. Parts of the plants used

\section{Method of preparation of plant-based medicines and their administration}

Local populations prefer the simplest preparation method for plant-based medicines and, according to the respondents of the survey, the powdered form of the aerial parts of the medicinal plant species was the only medicinal plant preparation used to treat CL (Figure 5).

The powdered medicinal preparations were administered alone or in the form of a poultice. The powdered plant or plant parts were mixed with butter, olive oil, honey, or cade oil to prepare a homogeneous paste, which was applied exogenously on the infected epidermis multiple times.

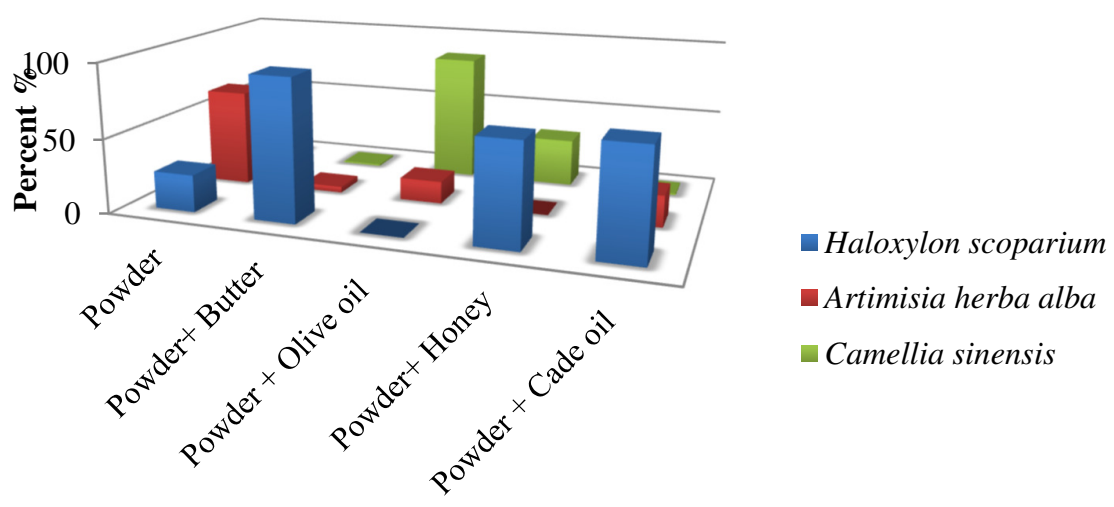

Mode of preparation

Figure 5. Methods of preparation of plant-based medicines using Haloxylon scoparium, Artemisia herbaalba, and Camellia sinensis

\section{Duration of treatment}

The recovery time of patients depends on the plant species used to treat CL (Figure 6), and the shortest recovery period was recorded in patients treated with $H$. scoparium ( $47 \%$ of the respondents). 


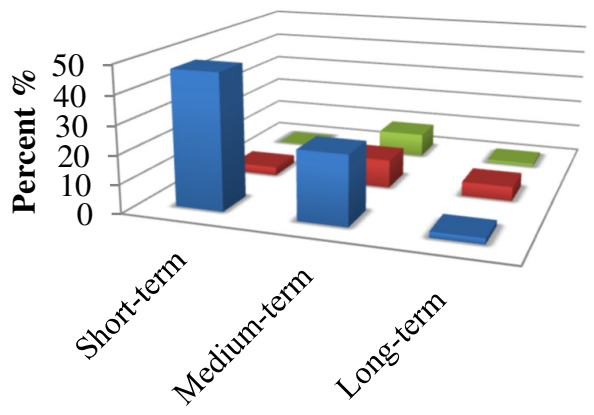

Haloxylon scoparium

- Artimisia herba alba

- Camellia sinensis

Time of recovery

Figure 6. Recovery time of patients treated with medicinal preparations of Haloxylon scoparium, Artemisia herba-alba, and Camellia sinensis

\section{Discussion}

The objective of the present study, conducted in the locality of Ain Sekhouna, Saida (southwest Algeria), was to identify plants used to treat zoonotic CL (also known as "Biskra nail"). Cutaneous leishmaniasisis caused by a flagellated protozoan Leishmania major and transmitted by Phlebotomus papatasi Scopoli (Diptera: Psychodidae). It was first described by Hamel in 1860; CL is endemic throughout the North Saharan fringe of the arid and semi-arid bioclimatic zone (Bachi, 2006). Although antimony salt-based treatment is used for leishmaniasis in the Algerian convergence, the Algerian population uses traditional medicines as an alternative to antimony salt-based medicines to prevent, limit, and treat super infections resulting from the disease.

This ethnopharmacological survey conducted in Ain Sekhouna is the first survey in the study area, wherein 100 interviewees identified three plant species that are used to treat skin lesions in CL. Moreover, $H$. scoparium was identified as the most widely used species for the treatment of CL in the study area by $73 \%$ of the respondents. These results agree with those of El Rhaffari et al. (2002), who showed that H. scoparium is the most cited plant species used to treat CL by the local population in the Oasis of Tafilelt, Morocco. This species is known for its pharmacological and biological properties and contains many bioactive compounds such as alkaloids (Li et al., 2010) and phenolic compounds (Haida et al., 2020), which are lethal to the promastigote form of Leishmania and prevent flagellum formation in macrophages (Mahmoudv et al., 2014) or inhibit the arginase activity that maintains the Leishmania population in the host (Manjolin et al., 2013).

A total of $8 \%$ and $9 \%$ of the respondents identified A. herba-alba and C. sinensis for the treatment of CL, both of which are used as plants with anti-leishmanial activity in their homes. Although members of the families Asteraceae and Theaceae have been used in traditional medicines to treat dermatological diseases (Salhi et al., 2010; Zeggwagh et al., 2013; Vandi et al., 2016), to the best of our knowledge, there have been no studies on the anti-leishmanial potential of $C$. sinensis.

The present survey also revealed that the aerial parts of the identified plant species constituted a major portion of the treatment (10\%-35\%). These findings are similar to those of previous studies (Jaradat et al., 2016; Wubetu et al., 2017). The use of these species and their parts can be explained by the fact that they are easily harvested (Doukkali et al., 2015) and their leaves are rich in biologically active secondary metabolites (Benabdesslem et al., 2017).

According to all the respondents, the powdered form of the medicinal preparations, which is applied exogenously as a poultice on the infected part of the epidermis, is the recommended mode of application. Previous studies on traditional medicines revealed that the poultice method of remedy preparation and external administration of the medicine are the only options for treating skin infections (Rettas et al., 2016; Hinds et 
al., 2017). This can be explained by the speed and efficacy of the poultice method, both of which depend on the type of disease and infection (Al-Qura'n, 2009; Zeouk et al., 2018). Furthermore, the remedies were prepared in butter, cade oil, olive oil, or honey to facilitate their action (Uzuna et al., 2004). These excipients are commonly used for dermatological treatment owing to their remarkable pharmacological and cosmetic properties (Koruk et al., 2005; Fontanel, 2012; Domerego et al., 2016).

\section{Conclusions}

In this study, we evaluated the use of plants to treat CL by the population of Ain Sekhouna; the study offered a practical approach to describe, valorize, and preserve local pharmacopeia, thereby preventing its uprooting.

The population of Ain Sekhouna exploits the biological properties of H. scoparium, A. herba-alba, and C. sinensis to prevent and treat CL. The preparation and administration of the remedies, that is, exogenous use of cataplasm, fit the logic of the galenic system. Overall, the findings of this study encourage further research in the field of phytochemistry, with the aim to identify novel natural active principles that can be used in pharmacology.

\section{Authors' Contributions}

Conceptualization and methodology: $\mathrm{MMH}$ and $\mathrm{KH}$; Investigation: AA; Formal analysis: $\mathrm{KH}$ and $\mathrm{MMH}$; Writing - original draft: AA and $\mathrm{KH}$. All authors read and approved the final manuscript.

\section{Acknowledgements}

This research received no specific grant from any funding agency in the public, commercial, or not-forprofit sectors.

\section{Conflict of Interests}

The authors declare that there are no conflicts of interest related to this article.

\section{References}

Al-Qura'n S (2009). Ethnopharmacological survey of wild medicinal plants in Showbak, Jordan. Journal of Ethnopharmacology 123:45-50. https://doi.org/10.1016/j.jep.2009.02.031

Anteur D, Mederbal K, Belhacini FZ, Baghdadi D, Gourari B, Marouf B (2016). Diagnosis of the floristic diversity of Ain Sekhouna (Steppe West-Algerian). International Journal of Biosciences 9:292-296. http://dx.doi.org/10.12692/ijb/9.4.292-296

Bachi F (2006). Aspects épidémiologiques et cliniques des leishmanioses en Algérie [Epidemiological and clinical aspects of leishmaniasis in Algeria]. La Lettre de l'infectiologue 21:9-15.

Benabdesslem Y, Hachem K, Kahloula K, Slimani M (2017). Ethnobotanical survey, preliminary physico-chemical and phytochemical screening of Salvia argentea (L.) used by herbalists of the Saïda Province in Algeria. Plants 6:59. https://doi.org/10.3390/plants6040059 
Benarba B, Belabid L, Righi K, Bekkar AA, Elouissi M, Khaldi A, Hamimed A (2015). Ethnobotanical study of medicinal plants used by traditional healers in Mascara (North West of Algeria). Journal of Ethnopharmacology 175:626637. https://doi.org/10.1016/j.jep.2015.09.030

Bhutto AM, Soomro RA, Nonaka S, Hashiguchi Y (2003). Detection of new endemic areas of cutaneous leishmaniasis in Pakistan:a 6-year study. International Journal of Dermatology 42:543-548. https://doi.org/10.1046/j.13654362.2003.01818.x

Bigo C (2011). La phytothérapie utilisée dans l'éréthisme cardiaque [Phytotherapy used in cardiac erethism]. PhD Thesis in Pharmacy, University of Lille,France.

Domerego R, Imbert, G, Blanchard C (2016). Guide pratique de la médecine des abeilles: miel, pollen, propolis, gelée royale... au quotidien [Practical guide to bee medicine: honey, pollen, propolis, royal jelly... in everyday life]. Baroch Eds, Norante, France.

Doukkali Z, Bouidida H, Srifi, A, Taghzouti K, Cherrah Y, Alaoui K (2015). Les plantes anxiolytiques au Maroc. Études ethnobotanique et ethno-pharmacologique [Anxiolytic plants in Morocco. Ethnobotanical and ethnopharmacological study]. Phytothérapie 13:306-313. https://doi.org/10.1007/s10298-015-0921-Z

El Rhaffari L, Hammani K, Benlyas M, Zaid A (2002). Traitement de la leishmaniose cutanée par la phytothérapie au Tafilalet [Treatment of cutaneous leishmaniasis by phytotherapy in Tafilalet]. Biologie et Santé 1:45-54.

Fontanel D (2012). Huiles et beurres de pulpes de fruits: revue des principales sources exploitées, teneurs en insaponifiables, propriétés et usages traditionnels d'intérêt cosmétique[Pulpy fruit oils and fats: Review of the main sources, unsaponifiable contents, properties and traditional uses related to interest incosmetics]. OCLOilseeds and fats, Crops and Lipids 19:232-237. https://doi.org/10.1051/ocl.2012.0442

Grol M, Thomason TN, Franke ED (1992). Drug resistance in leishmaniasis: its implication in systemic chemotherapy of cutaneous and mucocutaneous disease. American Journal of Tropical Medicine and Hygiene 47:117-126. https://doi.org/10.4269/ajtmh.1992.47.117

Haida S, Kribii A, Kribii A (2020). Chemical composition, phenolic content and antioxidant capacity of Haloxylon scoparium extracts. South African Journal of Botany 131:151-160. https://doi.org/10.1016/j.sajb.2020.01.037

Hamza N, Berke B, Umar A, Cheze C, Gin H, Moore N (2019). A review of Algerian medicinal plants used in the treatment of diabetes. Journal of Ethnopharmacology 238:111841.https://doi.org/10.1016/j.jep.2019.111841

Harrat Z, Hamrioui B, Belkaid M, Tabet-Derraz O (1995). Point actuel sur l'épidémiologie des leishmanioses en Algerie [Current statuts on the epidemiology of leishmaniasis in Algeria]. Bulletin de la Société de Pathologie Exotique 88:180-184.

Hinds L, Kenny O, Hossain MB, Walsh D, Sheehy E, Evans P, Gaffney M, Rai DK (2017). Evaluating the antibacterial properties of polyacetylene and glucosinolate compounds with further identification of their presence within various carrot (Daucus carota) and broccoli (Brassica oleracea) cultivars using high-performance liquid chromatography with a diode array detector and ultra-performanceliquid chromatography-tandem mass spectrometry analyses. Journal of Agricultural and Food Chemistry 65:7186-7191. https://doi.org/10.1021/acs.jafc.7b02029

Jaradat NA, Ayesh OI, Anderson C (2016). Ethnopharmacological survey about medicinal plants utilized by herbalists and traditional practitioner healers for treatments of diarrhoea in the West Bank/Palestine. Journal of Ethnopharmacology 182:57-66. https://doi.org/10.1016/j.jep.2016.02.013

Jones J, Bowlig J, Waston J, Viga-Lopez F, White J, Higgins E (2005). Old-world cutaneous leishmaniasis infection in children: a case series. Archives of Disease in Childhood 9:530-531. https://doi.org/10.1136/adc.2004.057968

Koruk ST, Ozyilkan E, Kaya P, Colak D, Donderici O, Cesaretli Y (2005). Juniper tar poisoning. Clinical Toxicology 43:47-49. https://doi.org/10.1081/CLT-45072

Li Y, Plitzko I, Zaugg J, Hering S, Hamburger M (2010). HPLC-based activity profiling for GABA receptor modulators: a new dihydroisocoumarin from Haloxylon scoparium. Journal of Natural Products 73:768-770. https://doi.org/10.1021/np900803w

Mahmoudvand H, Sharififar F, Sharifi I, Ezatpour B, Fasihi Harandi M, Makki MS, Zia-Ali N, Jahanbakhsh S (2014). In vitro inhibitory effect of Berberis vulgaris (Berberidaceae) and its main component, berberine against different Leishmania species. Iranian Journal of Parasitology 9:28-36.

Manjolin LC, dos Reis MB, Maquiaveli CC, Santos-Filho OA, da Silva ER (2013). Dietary flavonoids fisetin, luteolin and their derived compounds inhibit arginase, a central enzyme in Leishmania amazonensis infection. Food Chemistry 141:2253-2262. https://doi.org/10.1016/j.foodchem.2013.05.025 
McGwire BS, Satoskar AR (2013). Leishmaniasis: clinical syndromes and treatment. QJM: An International Journal of Medicine 107:7-14. https://doi.org/10.1093/qjmed/hct116

Miara MD, Bendif H, Ait Hammou H, Teixidor-Toneu I (2018). Ethnobotanical survey of medicinal plants used by nomadic peoples in the Algerian steppe. Journal of Ethnopharmacology 219:248-256. https://doi.org/10.1016/j.jep.2018.03.011

Rhattas M, Douira A, Zidane L (2016). Étude ethnobotanique des plantes médicinales dans le Parc National de Talassemtane (Rif occidental du Maroc) [Ethnobotanical study of medicinal plants in the Talassemtane Natural Park (Western Rif of Morocco)]. Journal of Applied Biosciences 97:9187-9211. http://dx.doi.org/10.4314/jab.v97i1.5

Salhi S, Fadli M, Zidane L, Douira A (2010). Etudes floristique et ethnobotanique des plantes médicinales de la ville de Kénitra (Maroc) [Floristic and ethnobotanical study of medicinal plants of Kénitra (Maroc)]. Lazaroa 31:133146. https://doi.org/10.5209/rev_LAZA.2010.v31.9

Tabuti JRS, lye KA, Dhillion SS (2003). Traditional herbal drugs of Bulamogi, Uganda: plants, use and administration. Journal of Ethnopharmacology 88:19-44. https://doi.org/10.1016/S0378-8741(03)00161-2

Uzuna E, Sariyar G, Adsersen A, Karacok B, Ötük G, Oktayuglo E, Pirildar S (2004). Traditional medicine in Sakarya province (Turkey) and antimicrobial activities of selected species. Journal of Ethnopharmacology 95:287-296. https://doi.org/10.1016/j.jep.2004.07.013

Vandi D, Nga EN, Betti JL, Loe GME, Ottou PBM, Priso RJ, Foze TN, Boumsong PCN, Dibong SD, Mpondo EM (2016). Contribution des populations des villes de Yaoundé et Douala à la connaissance des plantes à tanins et à anthocyanes[Contribution of the populations of the cities of Yaoundé and Douala to the knowledge of tannin and anthocyanin plants]. Journal of Animal and Plant Sciences 30:4797-4814.

Wubetu M, Abula T, Dejenu G (2017). Ethnopharmacological survey of medicinal plants used to treat human diseases by traditional medical practitioners in Dega Damot district, Amhara, Northwestern Ethiopia. BMC Research Notes 10:157. https://doi.org/10.1186/s13104-017-2482-3

Zeggwagh AA, Lahlou Y, Bousliman Y (2013). Survey of toxicological aspects of herbal medicine used by an herbalist in Fes, Morocco. Pan African Medical Journal 14:125. https://doi.org/10.11604/pamj.2013.14.125.1746

Zeouk I, El Ouali Lalami A, Ezzoubi Y, Derraz K, Balouiri M, Bekhti K (2020). Cutaneous leishmaniasis: medicinal plants used in Sefrou city (Centre of Morocco), a focus of leishmaniasis. Phytothérapie 18:187-194. https://doi.org/10.3166/phyto-2018-0060

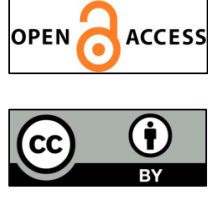

The journal offers free, immediate, and unrestricted access to peer-reviewed research and scholarly work. Users are allowed to read, download, copy, distribute, print, search, or link to the full texts of the articles, or use them for any other lawful purpose, without asking prior permission from the publisher or the author.

License - Articles published in Notulae Scientia Biologicae are Open-Access, distributed under the terms and conditions of the Creative Commons Attribution (CC BY 4.0) License.

(c) Articles by the authors; SHST, Cluj-Napoca, Romania. The journal allows the author(s) to hold the copyright/to retain publishing rights without restriction. 